\title{
Linking intellectual capital and intellectual property to company performance
}

\author{
Mohammad Reza Zahedi ${ }^{a^{*}}$, Reza Hosnavi ${ }^{\mathrm{b}}$ and Azam Kangogar ${ }^{\mathrm{c}}$
}

${ }^{a} \mathrm{PhD}$ in Industrial Engineering, Management Group, Malek Ashtar University, Tehran, Iran

${ }^{b}$ Associate Professor, Management Group, Malek Ashtar University, Tehran, Iran

cMasters Student, Management Group, Malek Ashtar University, Tehran, Iran

\section{H R O N I C L E}

Article history:

Received June 5, 2016

Received in revised format

October 2, 2016

Accepted October 19, 2016

Available online

October 19, 2016

Keywords:

Organizational performance

Human capital

Auto industry

\section{Introduction}

During the past few decades, there have been more attentions on intellectual capital in most organizations (Kavida \& Sivakoumar, 2010). The globalization of markets has led companies to gain competitive advantage through the creation of an internal intangible assets that are not easily being imitated by other organizations (Kaufmann \& Schneider, 2004). Nowadays, intangible assets such as intellectual capitals contribute significantly on firms' assets, which yield a good platform to improve workforce quality, customer satisfaction, innovation and competitiveness in today's competitive environment. Organizations need to rethink their assets and avoid one-dimensional looking at assets (Schneider, 2004). Hence, intellectual capital, as a vital and strategic asset, is considered as indicators of organizational performance and improving its quality. An appropriate platform for the identification and use of intellectual capital influences on intellectual capital as well as organizational performance compared with other financial tangible assets and physical assets. There are few studies on relationship between intellectual capital and firm performance although detecting which aspects of intellectual capital (structural, human, social) seems to be effective for the success of an organization (Bollen et

\footnotetext{
* Corresponding author.

E-mail address: zahedy182@gmail.com (M. R. Zahedi)

(C) 2016 Growing Science Ltd. All rights reserved.
}

\begin{abstract}
The purpose of this paper is to measure the effects of intellectual capital components; namely, industry. The study uses a questionnaire consists of 100 questions to cover intellectual capital and company performance in Likert scale and it is distributed among 180 experts in one of relational capital and structural capital are $0.82,0.80$ and 0.80 , respectively. In addition, Cronbach alpha for company performance is 0.82 . Using structural equation modeling, the study has determined a positive and meaningful relationship between intellectual capital and company
performance. The study has also determined a positive and meaningful relationship between human capital and structural capital. Among components of performance, efficiency maintained
\end{abstract}

(c) 2016 Growing Science Ltd. All rights reserved.

\footnotetext{
doi: $10.5267 /$ j.msl.2016.10.005
} 
al., 2005). In the late twentieth century, the global economy was undergone certain changes and these changes had significant impacts on economic growth and wealth creation (Andriessen, 2004; Chaharbaghi \& Cripps, 2006). Kim and Kumar (2009) investigated the effectiveness of the framework through the case study of a public sector research and development organization. They identified three major characteristics of the framework and provided a visual map, which could help management determine which indicators and related activities require more attention and should be improved. Chu et al. (2011) investigated the intellectual capital performance of Hong Kong firms and its association with business performance. An intellectual capital (IC) measurement, Value Added Intellectual Coefficient (VAICTM), was utilized to evaluate the IC investment of the companies. In their survey, no conclusive evidence was determined for having a relationship between VAICTM as an aggregate measure and the four financial indicators. Nevertheless, components of VAICTM were determined to forecast a significant variance in business performance. Capital Employed Efficiency (CEE), in their survey, was also determined to be an important factor in forecasting business financial performance. Structural Capital Efficiency (SCE) was also determined to have a substantial impact on businesses' market valuation. Negative correlations were also determined between Human Capital Efficiency (HCE) and the financial indicators. These findings have indicated a gap between the traditional accounting perspective and the value creation perspective.

Recently, there have been growing trend on Iranian auto industry and the effects of intellectual assets on this industry need to be examined. This paper presents an empirical investigation to study the relationship between these two factors.

\section{The proposed study}

The purpose of this paper is to measure the effects of intellectual capital components; namely, human capital, structural capital and relational capital on company performance in auto industry. The study uses a questionnaire consists of 100 questions to cover intellectual capital and company performance in Likert scale. The questionnaire was first distributed among some experts and the validity of the survey was confirmed. The population of the survey includes 310 managers and experts who worked for one of Iranian auto industry. The sample size is calculated as follows,

$$
n=\frac{N \times z_{\alpha / 2}^{2} \times p \times q}{\varepsilon^{2} \times(N-1)+z_{\alpha / 2}^{2} \times p \times q},
$$

where $N$ is the population size, $p=1-q$ represents the yes/no categories, $z_{\alpha / 2}$ is CDF of normal distribution and finally $\varepsilon$ is the error term. Since we have $p=0.5, z_{\alpha / 2}=1.96$ and $N=310$, the number of sample size is calculated as $n=168$. The survey distributes 180 questionnaires and managed to collect 162 properly filled ones. Cronbach alphas for intellectual capital components, i.e. human capital, relational capital and structural capital are $0.82,0.80$ and 0.80 , respectively. In addition, Cronbach alpha for company performance is 0.82 . These numbers are well above the minimum acceptable level of 0.70 and the reliability of the questionnaire has been confirmed. Fig. 1 shows the structure of the proposed study.

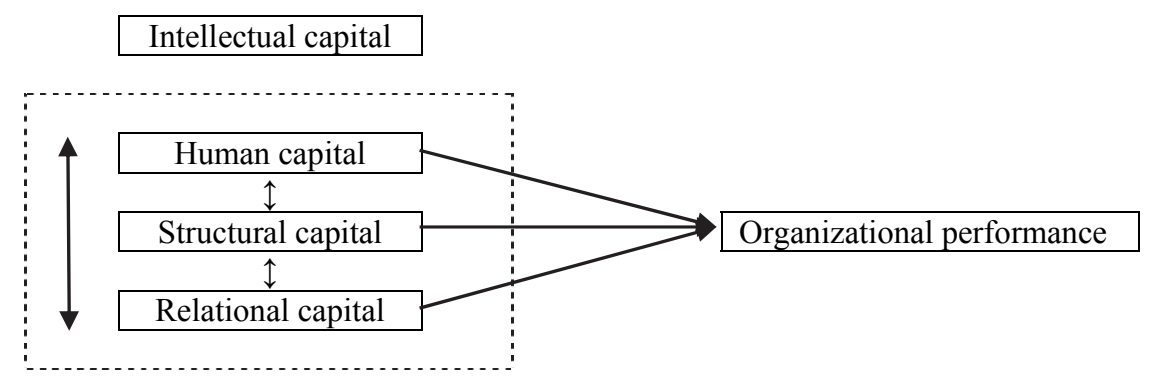

Fig. 1. The structure of the proposed study 
According to Fig. 1, there are four hypotheses associated with the proposed study of this paper as follows,

$\mathrm{H}_{1}$ : Intellectual property influences positively on organizational performance.

$\mathrm{H}_{2}$ : Human capital influences positively on organizational performance.

$\mathrm{H}_{3}$ : Relational capital influences positively on organizational performance.

$\mathrm{H}_{4}$ : Structural capital influences positively on organizational performance.

Table 1 demonstrates the components and variables used for the proposed study of this paper.

Table 1

The components of the survey

\begin{tabular}{|c|c|c|}
\hline Major component & Sub-component & Symbol \\
\hline \multirow{3}{*}{ Human capital } & Competence and capability & Comp \\
\hline & Knowledge & Know \\
\hline & Creativity and innovation & InnCre \\
\hline \multirow{7}{*}{ Structural capital } & Goals and organizational strategies & Objst \\
\hline & Structure & Str \\
\hline & Organizational culture & $\mathrm{Cul}$ \\
\hline & Information system & InfSys \\
\hline & Process & Proc \\
\hline & Infrastructure & Infra \\
\hline & Effectiveness & Eff \\
\hline \multirow{2}{*}{ Relational capital } & Cognitive & $\operatorname{Cog}$ \\
\hline & Relational & Rel \\
\hline \multirow{5}{*}{ Organizational performance } & Organizational effectiveness & OrgEff \\
\hline & Customer satisfaction & CusSat \\
\hline & Preference procedure & PerfProc \\
\hline & Intellectual & Intelect \\
\hline & Innovation & Innov \\
\hline
\end{tabular}

We have used structural equation modeling the measure the effects of different factors. We first remove the items whose factor loading measures were below 0.4 and then rerun the model. Next, we present the results of our study.

\section{The results}

Table 2 presents the results of factor loading measures for the adjusted model.

Table 2

The summary of the factor loading measures

\begin{tabular}{|c|c|c|c|c|c|}
\hline Measure & Human capital & Structural capital & Relational capital & Intellectual capital & Organizational \\
\hline Know & 0.92 & & & & \\
\hline Know & & & & 0.838 & \\
\hline InnCre & 0.924 & & & & \\
\hline InnCre & & & & 0.844 & \\
\hline Objst & & 0.733 & & & \\
\hline Objst & & & & 0.695 & \\
\hline Str & & 0.878 & & & \\
\hline Str & & & & 0.844 & \\
\hline $\mathrm{Cul}$ & & 0.836 & & & \\
\hline $\mathrm{Cul}$ & & & & 0.807 & \\
\hline InfSys & & 0.858 & & & \\
\hline InfSys & & & & 0.834 & \\
\hline Infra & & 0.623 & & & \\
\hline Infra & & & & 0.597 & \\
\hline Eff & & 0.768 & & & \\
\hline Eff & & & & 0.797 & \\
\hline $\operatorname{Cog}$ & & & 0.898 & & \\
\hline $\operatorname{Cog}$ & & & & 0.813 & \\
\hline Rel & & & 0.838 & & \\
\hline Rel & & & & 0.723 & \\
\hline OrgEff & & & & & 0.881 \\
\hline CusSat & & & & & 0.863 \\
\hline PerfProc & & & & & 0.896 \\
\hline Intelect & & & & & 0.858 \\
\hline Innov & & & & & 0.864 \\
\hline
\end{tabular}


In our survey, we have used two factors; namely Cronbach alpha and Composite Reliability to validate the model and Table 3 presents the results of our investigation. As we can observe from the results, all components preserve desirable values and they are within the desirable levels. Table 4 shows the results of correlation among different components of the survey.

Table 3

The results of Cronbach alpha, AVE and Composite Reliability

\begin{tabular}{lccc}
\hline Measure & Cronbach alpha & Composite reliability & AVE \\
\hline Human capital & 0.825 & 0.919 & 0.851 \\
Structural capital & 0.875 & 0.906 & 0.720 \\
Relational capital & 0.678 & 0.86 & 0.755 \\
Intellectual capital & 0.928 & 0.94 & 0.613 \\
Organizational & 0.921 & 0.941 & 0.761 \\
\hline
\end{tabular}

Table 4

The summary of the correlations among different components of the survey

\begin{tabular}{|c|c|c|c|c|c|}
\hline Measure & $\begin{array}{c}\text { Human } \\
\text { capital }\end{array}$ & $\begin{array}{c}\text { Structural } \\
\text { capital }\end{array}$ & $\begin{array}{c}\text { Relational } \\
\text { capital }\end{array}$ & $\begin{array}{c}\text { Intellectual } \\
\text { capital }\end{array}$ & $\begin{array}{c}\text { Organizational } \\
\text { performance }\end{array}$ \\
\hline Human capital & 0.922 & & & & \\
\hline Structural capital & $\overline{0.839}$ & $\underline{0.848}$ & & & \\
\hline Relational capital & 0.75 & $\overline{0.808}$ & $\underline{0.869}$ & & \\
\hline Intellectual capital & - & - & - & - & \\
\hline Organizational performance & 0.733 & 0.801 & 0.847 & - & $\underline{0.872}$ \\
\hline
\end{tabular}

The results of Table 4 have indicated that there were positive and meaningful relationships among different pairs of the components. Table 5

Table 5

The results of communality, R-Square and Goodness of fitness for the proposed model

\begin{tabular}{lccc} 
Measure & Communality & $\mathrm{R}^{2}$ & Goodness of fit (GOF) \\
\hline Human capital & 0.851 & 0.831 & \\
Structural capital & 0.62 & 0.954 & 0.787 \\
Relational capital & 0.755 & - & 0.779 \\
Intellectual capital & 0.613 & 0.804 & \\
Organizational & 0.761 & 0.844 & \\
\hline Mean & 0.72 & \\
\hline
\end{tabular}

As we can observe from the results of Table 5, all components provide desirable values and in overall, goodness of fit maintains acceptable value. Finally, Table 6 shows the results of path analysis and we can learn that all hypotheses of the survey have been confirmed when the level of significance is five percent $(\alpha=5 \%)$.

Table 6

The results of path analysis

\begin{tabular}{ccccccc}
\hline Item & Hypothesis & Independent variable & Dependent variable & Path coefficient & t-student & Result \\
\hline 1 & Main & Intellectual capital & $\begin{array}{c}\text { Organizational } \\
\text { performance }\end{array}$ & 0.76 & 22.515 & Confirmed \\
2 & $1^{\text {st }}$ sub-hypothesis & Human capital & $\begin{array}{c}\text { Organizational } \\
\text { performance }\end{array}$ & 0.733 & 9.419 & Confirmed \\
3 & $2^{\text {nd }}$ sub-hypothesis & Structural capital & $\begin{array}{c}\text { Organizational } \\
\text { performance }\end{array}$ & 0.801 & 14.885 & Confirmed \\
4 & $3^{\text {rd }}$ sub-hypothesis & Relational capital & $\begin{array}{c}\text { Organizational } \\
\text { performance }\end{array}$ & 0.847 & 11.144 & Confirmed
\end{tabular}


We have also performed Freedman ranking test to rank different components of the survey. In our survey, organizational culture is the most important factor (mean rank $=3.740$ ) followed by organizational structure (mean rank $=3.648$ ), Goals and organizational strategies (mean rank $=3.595$ ), information systems (mean rank $=3.523$ ), infrastructure (mean rank $=3.247$ ) and effectiveness (mean rank $=3.247)$. In terms of relational capital, cognitive capital performs (mean rank $=1.57$ ) better than relational capital (mean rank $=1.430)$.

In terms of organizational performance, organizational effectiveness is the most important factors (mean rank $=3.21)$ followed by customer satisfaction (mean rank $=3.04)$, process (mean rank $=2.99$ ), intellectual property (mean rank $=2.91)$ and innovation (mean rank $=2.85)$.

\section{Conclusion}

In this paper, we have presented an empirical investigation to study the effects of intellectual capital on organizational performance for a case study of auto industry. The proposed study designed a questionnaire and distributed it among some experts who worked for an auto maker in Iran. The results have indicated that all components of the survey maintained positive and meaningful impacts on organizational performance. The results of this survey are consistent with findings earlier reported by Bontis (2002), Bontis et al. (2002), Bontis (2003) and María Díez et al. (2010) but they are not in line with findings of Mavridis $(2004,2005)$ and Chen (2004). The study has also determined a positive and meaningful relationship between human capital and structural capital. Among components of performance, efficiency maintained the highest effect while innovation represents the minimum effect.

\section{Acknowledgement}

The authors would like to thank the anonymous referees for constructive comments on earlier version of this paper.

\section{References}

Andriessen, D. (2004). IC valuation and measurement: classifying the state of the art. Journal of intellectual capital, 5(2), 230-242.

Bollen, L., Vergauwen, P., \& Schnieders, S. (2005). Linking intellectual capital and intellectual property to company performance. Management Decision, 43(9), 1161-1185.

Bontis, N. (2002). National intellectual capital index: Intellectual capital development in the Arab Region. Institute for Intellectual Capital Research, Ontario.

Bontis, N., Crossan, M. M., \& Hulland, J. (2002). Managing an organizational learning system by aligning stocks and flows. Journal of management studies, 39(4), 437-469.

Bontis, N. (2003). Intellectual capital disclosure in Canadian corporations.Journal of Human Resource Costing \& Accounting, 7(1), 9-20.

Chaharbaghi, K., \& Cripps, S. (2006). Intellectual capital: direction, not blind faith. Journal of Intellectual Capital, 7(1), 29-42.

Chen, J., Zhu, Z., \& Yuan Xie, H. (2004). Measuring intellectual capital: a new model and empirical study. Journal of Intellectual capital, 5(1), 195-212.

Chu, S. K. W., Chan, K. H., Yu, K. Y., Ng, H. T., \& Wong, W. K. (2011). An empirical study of the impact of intellectual capital on business performance.Journal of Information \& Knowledge Management, 10(01), 11-21.

Kaufmann, L., \& Schneider, Y. (2004). Intangibles: a synthesis of current research. Journal of Intellectual Capital, 5(3), 366-388.

Kavida, V., \& Sivakoumar, N. (2010). The relevance of intellectual capital in the Indian information technology industry. IUP Journal of Knowledge Management, 8(4), 25. 
Kim, D. Y., \& Kumar, V. (2009). A framework for prioritization of intellectual capital indicators in R\&D. Journal of Intellectual Capital, 10(2), 277-293.

María Díez, J., Lizet Ochoa, M., Begona Prieto, M., \& Santidrian, A. (2010). Intellectual capital and value creation in Spanish firms. Journal of intellectual capital, 11(3), 348-367.

Mavridis, D. G. (2004). The intellectual capital performance of the Japanese banking sector. Journal of Intellectual Capital, 5(1), 92-115.

Mavridis, D. G. (2005). Intellectual capital performance determinants and globalization status of Greek listed firms. Journal of Intellectual Capital, 6(1), 127-140.

Schneider, D. K. Y. (2004). Intangibles: A synthesis of current research.Journal of Intellectual Capital, 5(3).

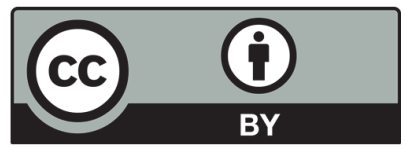

(C) 2016 by the authors; licensee Growing Science, Canada. This is an open access article distributed under the terms and conditions of the Creative Commons Attribution (CC-BY) license (http://creativecommons.org/licenses/by/4.0/). 